\title{
Anti Müllerian Hormone (AMH) Level as Ovarian Reserve Marker before and after Cystectomy Laparotomy
}

\section{Kadar Anti Müllerian Hormone (AMH) sebagai Penanda Cadangan Ovarium sebelum dan sesudah Tindakan Laparotomi Kistektomi}

\author{
Rosdiana Sahabuddin, Nusratuddin Abdullah, IMS Murah Manoe \\ Department of Obstetrics and Gynecology \\ Faculty of Medicine Universitas Hasanuddin/ \\ Dr. Wahidin Sudiro Husodo Hospital \\ Makassar
}

\begin{abstract}
Objective: To investigate the comparison of the Anti-Mullerian Hormone (AMH) as the ovarian reserve marker before and after cystectomy.

Methods: This study used prospective cohort design which included all women with the ovarian cyst who underwent cystectomy laparotomy. The subjects were examined AMH level before and after the procedure. Data were analyzed using one- way Anova, T- paired test, and T-independent test with $\mathrm{p}$ value $<0.05$ considered significantly.
\end{abstract}

Results: We obtained 40 subjects consisting of 21 women $(52.5 \%)$ suffering endometriosis cyst, 12 women (30.0\%) suffering functional cyst, and 7 others (17.5\%) suffering dermoid cyst. After the cystectomy, AMH level was different between endometriosis cyst and non-endometriosis cyst patients; whereas, the endometriosis cyst group showed greater decrease of AMH level $(p<0.05)$. The mean AMH level in the cyst women before cystectomy laparotomy was 2.9 (SD 0.4 ) $\mathrm{ng} / \mathrm{ml}$ and after the surgery, the mean value became 1.9 (SD 0.6$) \mathrm{ng} / \mathrm{ml}$.

Conclusion: The decrease of AMH level is significant in the endometrial ovarian cyst women who undergo the cystectomy.

[Indones J Obstet Gynecol 2017; 5-1: 30-34]

Keywords: Anti Müllerian Hormone, laparotomy, ovarian cystectomy, ovarian reserve

\begin{abstract}
Abstrak
Tujuan: Untuk mengetahui perbandingan kadar Anti Mullerian Hormone (AMH) sebagai penanda cadangan ovarium sebelum dan sesudah kistektomi.

Metode: Penelitian ini menggunakan desain kohort prospektif. Semua perempuan dengan kista ovarium yang dilakukan kistektomi diperiksa untuk mengetahui perbedaan tingkat AMH sebelum dan setelah kistektomi. Data dianalisis dengan uji oneway Anova, $T$ - paired test dan $T$ independent dengan nilai $p<0,05$ adalah bermakna.

Hasil: Kami mendapatkan 40 sampel, yang terdiri dari 21 orang penderita kista endometriosis (52,5\%), 12 penderita kista fungsional (30,0\%), 7 penderita kista dermoid (17,5\%). Setelah kistektomi, penderita kista endometriosis dan kista non endometriosis menunjukkan perbedaan tingkat $A M H$, yaitu pada pasien kista endometriosis menunjukkan penurunan tingkat $A M H(p<0,05)$ Rata-rata kadar AMH penderita kista sebelum operasi kistektomi $2,9(S B 0.4) \mathrm{ng} / \mathrm{ml}$, dan setelah operasi dengan nilai rata-rata 1,9 (SB 0.6) $\mathrm{ng} / \mathrm{ml}$.
\end{abstract}

Kesimpulan: Penurunan kadar AMH terjadi secara bermakna pada pasien kista ovarium yang dilakukan tindakan kistektomi dengan penurunan yang lebih banyak pada kelompok kista endometriosis. [Maj Obstet Ginekol Indones 2017; 5-1: 30-34]

Kata kunci: Anti Müllerian Hormone, cadangan ovarium, laparotomi kistektomi

Correspondence: Rosdiana Sahabuddin, rosdiana.sahabuddin@yahoo.com

\section{INTRODUCTION}

The ovarian mass mostly has cystic form. The incidence of ovarian cyst was reported between 5 and 15 percent of all gynecological diseases. ${ }^{1}$

Generally, the most common ovarian cysts is functional cyst, followed by endometriosis and dermoid cysts. Each type of cyst has its own characteristics so that we have to be careful in performing cystectomy to avoid the damage of ovaries. In women with ovarian cysts who undergo cystectomy, ovarian tissue damage may occur. It happens when normal tissue is removed due to the heat effect or cauterization process. Normal ovarian tissue should be maintained as much as possible because it is related to fertility condition signed by the ability of the ovaries to hold ovulation. ${ }^{2}$

Anti-Mullerian Hormone (AMH) is a homodimeric glycoprotein sulfide bond to TGF- $\beta$ group with molecular weight $140 \mathrm{kDa}$. It is a hormone that is produced by the granulosa cells of primary ovarian follicles and it plays a major role in the growth and differentiation of cells. The highest 
expression is located in the follicular phase preantral and small antral follicles, and it will be no longer detectable when follicles undergo atresia. Level of serum AMH is strongly associated with the number of antral follicles.The AMH level describes the remaining of primordial follicles that reserved, which can be used as an illustration of ovulation induction success. The greater the ovarian tissue damage after cystectomy, the less number of normal follicles; thus, it will decrease AMH level after surgery. ${ }^{3}$

Ovarian reserve is a potential ovarian function that reflects the number and quality of remaining primordial follicles at such time. In the last two decades, serum AMH, Follicle Stimulating Hormonne ( $\mathrm{FSH}$ ), Estradiol ( $\left.\mathrm{E}_{2}\right)$, and inhibin $\mathrm{B}$ have been used as marker of ovarian reserve. However, inhibin B, FSH and $\mathrm{E}_{2}$ level fluctuate during the menstrual cycle; while, the level of serum AMH is relatively stable throughout the menstrual cycle. Therefore, $\mathrm{AMH}$ is better marker for predicting ovarian response than age, FSH, or inhibin B. A lot of studies used AMH as a marker of the ovarian reserve damage rate due to ovarian cystectomy. ${ }^{2}$

Measurement of serum AMH level is more easily performed than hyperstimulation of ovarian to predict ovarian reserve. It is stated that the change of ovarian reserve can be measured through serial measurement of serum AMH level which reflects the number of primordial follicles after ovarian surgery. ${ }^{4}$

Based on these ideas, we conducted a study which included all women with kinds of ovarian cysts undergo cystectomy surgery. The level of serum AMH on each type of cyst was measured before surgery, then repeated subsequently after surgery to determine the fluctuation of AMH level. Therefore, this study aims to investigate the comparison of the AMH as the ovarian reserve marker before and after cystectomy.

\section{METHODS}

This study was a prospective cohort design which was conducted in several teaching hospitals of Obstetrics and Gynecology Department, Faculty of Medicine Universitas Hasanuddin, Makassar from Desember 2014 to July 2015. The population was women with ovarium cyst examing in hospital. Subjects who met the criteria offered to participate in this study and they had to sign the informed consent. All blood samples were taken and examined in Nehri Laboratory of Universitas Hasanuddin Hospital. We processed the data using SPSS through one-way Anova, T-independent test, and T-paired test. Hypothesis testing was considered significantly if $\mathrm{p}<0.05$

\section{RESULTS}

There were 40 subjects consisting of 21 patients with endometriosis cysts, 12 patients with functional cyst, and 7 patients with dermoid cyst. In this study, there was not difference in age, parity, body mass index, level of CA 125, and symmetry between endometriosis cysts, functional cysts, and dermoid cysts ( $\mathrm{p}>0.05)$ (Table 1).

Table 1. Subjects' Characteristics

\begin{tabular}{|c|c|c|c|c|c|c|c|}
\hline \multirow{2}{*}{ Variable } & \multicolumn{2}{|c|}{$\begin{array}{l}\text { Endometriosis cysts } \\
\qquad(n=21)\end{array}$} & \multicolumn{2}{|c|}{$\begin{array}{l}\text { Functional cysts } \\
\qquad(n=12)\end{array}$} & \multicolumn{2}{|c|}{$\begin{array}{l}\text { Dermoid Cysts } \\
(n=7)\end{array}$} & \multirow{2}{*}{ p Value } \\
\hline & $\mathbf{N}$ & $\%$ & $\mathbf{N}$ & $\%$ & $\mathbf{N}$ & $\%$ & \\
\hline \multicolumn{8}{|c|}{ Age (years old) } \\
\hline $20-30$ & 16 & 64.0 & 7 & 28.0 & 2 & 8.0 & 0.074 \\
\hline $31-40$ & 5 & 33.3 & 5 & 33.3 & 5 & 33.3 & \\
\hline \multicolumn{8}{|l|}{ Parity } \\
\hline 0 & 14 & 60.9 & 7 & 30.4 & 2 & 8.7 & 0.198 \\
\hline 1 & 7 & 50.0 & 3 & 22.4 & 4 & 28.6 & \\
\hline 2 & 0 & 0 & 2 & 66.7 & 1 & 33.3 & \\
\hline \multicolumn{8}{|l|}{ IMT } \\
\hline Abnormal & 4 & 40.0 & 4 & 40.0 & 2 & 20.0 & 0.641 \\
\hline Normal & 17 & 56.7 & 8 & 26.7 & 5 & 16.7 & \\
\hline
\end{tabular}




\begin{tabular}{lccccccc}
\hline \hline \multirow{2}{*}{ Variable } & \multicolumn{2}{c}{$\begin{array}{c}\text { Endometriosis cysts } \\
(\mathbf{n = 2 1 )}\end{array}$} & \multicolumn{2}{c}{$\begin{array}{c}\text { Functional cysts } \\
(\mathbf{n = 1 2})\end{array}$} & \multicolumn{2}{c}{$\begin{array}{c}\text { Dermoid Cysts } \\
(\mathbf{n = 7})\end{array}$} & p Value \\
\cline { 2 - 6 } & $\mathbf{N}$ & $\mathbf{\%}$ & $\mathbf{N}$ & $\mathbf{\%}$ & $\mathbf{N}$ & $\mathbf{\%}$ & \\
\hline CA 125 Level & & & & & & & \\
Abnormal & 12 & 100 & 0 & 0 & 0 & 0 & $<0.001$ \\
Normal & 9 & 32.1 & 12 & 42.9 & 7 & 25.0 & \\
Symmetry & & & & & & & \\
Bilateral & 11 & 68.8 & 3 & 18.8 & 2 & 12.5 & 0.241 \\
Unilateral & 10 & 41.7 & 9 & 37.5 & 5 & 20.8 & \\
\hline \hline
\end{tabular}

Table 2. AMH Level between Endometriosis and Non-Endometriosis Cyst

\begin{tabular}{lccccc}
\hline \hline \multirow{2}{*}{ AMH Level } & \multicolumn{2}{c}{$\begin{array}{c}\text { Endometriosis Cysts } \\
\text { (n= 21) }\end{array}$} & SD & Mean & Non-Endometriosis \\
Cysts (n= 19) & SD & p-value \\
\cline { 2 - 5 } & Mean & 0.3 & 3.1 & 0.4 & $0.001^{*}$ \\
Before cystectomy & 2.7 & 0.4 & 2.4 & 0.4 & $<0.001^{*}$ \\
\hline \hline
\end{tabular}

Table 3. Comparison Distribution AMH Level all Samples before Cystectomy and after Cystectomy

\begin{tabular}{lcccccc}
\hline \hline \multirow{2}{*}{ Variable } & \multicolumn{3}{c}{$\begin{array}{c}\text { Before Cystectomy } \\
(\mathbf{n = 4 0 )}\end{array}$} & \multicolumn{4}{c}{$\begin{array}{c}\text { After Cystectomy } \\
\text { (n= 40) }\end{array}$} & p-value \\
\cline { 2 - 6 } & Mean & SD & Mean & SD & $<0.001^{*}$ \\
\hline AMH & 2.9 & 0.4 & 1.9 & 0.6 & $<$ \\
\hline \hline
\end{tabular}

Table 2 showed the average level of AMH before and after cystectomy on endometriosis also nonendometriosis cyst women. Before cystectomy through laparotomy, the mean of AMH level on endometriosis and non-endometriosis cyst group was 2.7 (SD 0.3) ng/ml and 3.1 (SD 0.4) ng/ml. The statistical test result using independent $\mathrm{t}$-test showed there was difference in AMH level before cystectomy in patients with endometriosis and non-endometriosis cyst $(\mathrm{p}=0.001)$. The mean of AMH level after cystectomy was greater on both types (1.5 (SD 0.4) ng/ml and 2.4 (SD 0.4) ng/ml). Apart from that, the statistical result showed significantly different between groups $(\mathrm{p}<0.001)$.

Table 3 pointed out the mean level of $\mathrm{AMH}$ before and after cystectomy. There was a decrease trend of AMH level before and after cystectomy. The statistical test resulted the significant difference between this group $(\mathrm{p}<0.001)$.

\section{DISCUSSION}

The results of statistical test performed in this study showed the baseline characteristics of subjects were similar between groups so that these data would not influence the result of statistical test. Chang, et al. showed the decrease of AMH level one week after cystectomy and they found that AMH level would have recovery after 1 month and 3 months. The serum AMH level increased gradually after cystectomy and recovered about $65 \%$ after 3 months. There were several hypothesizes about the mechanism recovery of this AMH. Firstly, improvement of serum AMH level reflected the possibility of ovarian tissue reperfusion so that it released the AMH that normally produced by ovarian follicles group after forming the ovary blood vessel. Secondly, there was compensation in the form of hyperactivation on granulosa cells to produce the remaining follicle in ovary as the response of damage. 
Although the number of follicles might decline after ovarian cystectomy, the amount of $\mathrm{AMH}$ secretion per follicle could be improved. Inflammation after surgery could stimulate ovarian follicle regeneration. Thirdly, some researchers speculated that the follicle could be saved from the follicle atresia. ${ }^{4}$

Study by Hirokawa and colleagues measured level of serum AMH before cystectomy and one month after laparoscopic cystectomy. They performed to 38 patients with endometrioma (20 unilateral and 18 bilateral). Serum AMH level significantly decreased after surgery. The decline in AMH level was found to correlate with bilateral cysts, not to diameter of cysts and age. Hirokawa, et al. also indicated the ovulation rate was significantly decreased in the ovary after cystectomy compared with before cystectomy. ${ }^{5}$

The measurement of AMH level after surgery dropped significantly after cystectomy and it occurred greater on endometriosis cyst. On cystectomy, a decline of AMH level might happen due to the removal of ovarian parenchyma during excision of the cyst wall. According to Roman, it was commonly occurred because as histologically, there was no barrier between the fields lining of the cyst and ovarian cortex. Therefore, the operator had to estimate the excision of cyst wall so that it increased the risk of ovarian cortex damage which finally contributed to the reduction of ovarian reserve. ${ }^{6}$ In endometriosis cyst, there was no obvious barrier field due to fibrosis. This often led to accidentally remove number of ovarian cortex adjacent to the cyst wall and bleeding could occur in the hilum of the ovary; thus, the procedure required electrocoagulation that interfered with blood flow to the ovaries which were ended to reduce functional ovarian reserve. $^{7}$ The decrease of serum AMH level was caused by accidentally removing of normal ovarian cortex, damaging due to coagulation electro surgery during hemostasis, or injury due to inflammation. All of them would result to healthy follicle loss. ${ }^{4,8,9}$

Cystectomy in endometriosis cyst caused more damage than the ovarian cystectomy on functional cyst. Removal of benign ovarian cyst would takeaway the ovarian tissue; however, this adverse effect was lighter than cystectomy in endometriosis cyst. ${ }^{10}$ Muzii, et al. hypothesized that this difference was caused by pseudocapsule in endometriosis cyst compared with clear capsule in non-endometriosis cysts in order to make separate fields and clear dissection area. Muzii, et al. showed the non-endometriosis cyst which had clear cyst wall (dermoid or functional cyst) resulted to normal ovarian tissue only in $6 \%$ of cases; while, in excision of endometriosis cyst, the normal ovarian tissue was found higher to $54 \%$ of cases. ${ }^{11}$

Repair follicles may allow improvement of serum AMH level. It is because AMH is produced by the primary follicle, antral follicle, and small antral follicles. Developing follicles which are damaged after cystectomy will result to the lower level of serum AMH. Healthy primordial follicles are left behind because recruitment and growth of primordial follicle take time to produce $\mathrm{AMH}$. Folliculogenesis from primordial follicles become preovulatoar follicle about 85 days. ${ }^{12,13}$

\section{CONCLUSION}

The decrease of AMH level is significant in the endometrial ovarian cyst women who undergo the cystectomy.

\section{RECOMMENDATION}

Further study in a serial and longer follow-up is needed to look the fluctuation trend of AMH level after cystectomy at 1,3 , and 6 months after procedure.

\section{REFFERENCES}

1. Schorge. Pelvic mass: Cystic ovarian masses. In: Williams gynecology. Texas: McGraw Hill. 2008.

2. Hwu YM. The impact of endometrioma and laparoscopic cystectomy on serum anti Mullerian hormone levels. Reprod Biol Endocrinol. 2011; 9: 80.

3. Visser JA. Anti Mullerian Hormone-a new marker for ovarian function. Reprod. 2006; 131: 1-9.

4. Chang H. Impact of laparoscopic cystectomy on ovarian reserve: serial changes of serum Anti Mullerian Hormone levels. Fertil Steril. 2010; 94: 343-9.

5. Hirokawa W. The post operative decline in serum anti Mullerian Hormone correlates with the bilaterality and severity of endometriosis. Hum Reprod. 2011; 26: 904-10.

6. Roman H. Antimullerian Hormone level and endometrioma ablation using plasma energy. J Soc Laparoendoscopic Surg. 2014; 18.

7. Tsolakidis. The impact on ovarian reserve after laparoscopic ovarian cystectomy versus three-stage management 
in patients with endometriomas: A prospective randomized study. Fertil Steril. 2010; 94: 71-7.

8. Jang WK. Surgical impact on serum Anti-Müllerian Hormone in women with benign ovarian cyst: A prospective study. Obstet Gynecol Science. 2014; 57: 121-7.

9. Tiarma. The effect of analog GnRH before laparoscopic cystectomy to ovarian reserve which was measured with Anti Müllerian Hormone at bilateral endometriosis cyst. Indones J Obstet Gynecol. 2011; 35: 14-7.

10. Lee DY. Effects of laparoscopic surgery on serum AntiMullerian Hormone levels in reproductive-aged women with endometrioma. Gynecol Endocrinol. 2011; 27: 733-6.
11. Muzii L. Laparoscopic stripping of endometriomas: a randomized trial on different surgical techniques. Part II: Pathological results. Hum Reprod. 2005; 20: 1987-92.

12. Sugita A. One-year follow-up of serum Anti Mullerian Hormone levels in patients with cystectomy: Are different sequential changes due to different mechanisms causing damage to the ovarian reserve? Fertil Steril. 2013; 100: 516-22.

13. Speroff L. Female infertility. In: Clinical Gynecologic, Endocrinology and Infertility. Philadelphia: Lippincott Williams \& Wilkins. 2011. 